\title{
Investigations on some zeolitic volcanic tuffs from Cluj County (Romania), used for zinc ions removal from aqueous solution
}

\author{
Horea BEDELEAN ${ }^{*}$, Andrada MĂICĂNEANU ${ }^{2}$, Silvia BURC $\check{A}^{2} \&$ Maria STANCA $^{2}$ \\ ${ }^{1}$ Department of Geology, “Babeş-Bolyai” University, Kogălniceanu 1, 400084 Cluj Napoca, Romania \\ ${ }^{2}$ Department of Chemical Technology, "Babeş-Bolyai” University, Arany Janos 11, 400028 Cluj Napoca, Romania
}

Received October 2009; accepted February 2010

Available online 27 April 2010

DOI: $10.5038 / 1937-8602.55 .1 .2$

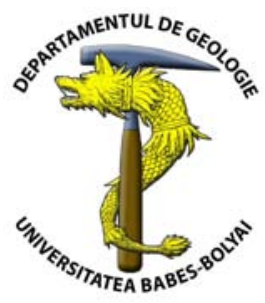

\begin{abstract}
Representative samples of zeolitic tuffs from Măcicaş, Aluniş, and Apahida occurrences (Cluj County, Romania) were investigated using optical microscopy, scanning electron microscopy (SEM), X-ray diffraction (XRD) and wet chemical analyses. The studied tuff samples are represented mainly by vitric and vitric crystal varieties. The mineral assemblage suggests a rhyodacitic volcanic tuff. Diagenetic alteration led to the formation of zeolites, mainly clinoptilolite. $\mathrm{Zn}^{2+}$ removal was performed on some bulk samples: Aluniş (labelled A1), Apahida (Ap), and Măcicaş (M2) grain size of 0.2-0.4 mm. Each sample was chemically modified with $\mathrm{HCl} 1 \mathrm{M}(\mathrm{Z}-\mathrm{H}$ form) and $\mathrm{NaCl}+\mathrm{NaOH} 1 \mathrm{M} \mathrm{pH}=10$ (Z-Na form). The ionic exchange experiments were performed in a batch reactor (immobile phases) and in a fixed bed column. Ionic exchange efficiencies for the samples considered are presented for static and dynamic regimes. Removal efficiencies higher than $53.97 \%$ and exchanged $\mathrm{Zn}^{2+}$ quantities higher than $1.05 \mathrm{mg} / \mathrm{g}$ were obtained. Therefore, the zeolitic tuffs under investigation are considered to be active in the ionic exchange process and can be used in wastewaters treatment to remove $\mathrm{Zn}^{2+}$ ions. The results for all the samples considered in batch and fixed bed experiments are presented by means of cation exchange capacity (CEC) and removal efficiency.
\end{abstract}

Key words: natural zeolites, clinoptilolite, volcanic tuffs, Cluj County, zinc, ionic exchange.

\section{INTRODUCTION}

Zeolites are a group of hydrated aluminosilicates of the alkali or alkaline earth metals ( $\mathrm{Na}, \mathrm{K}, \mathrm{Mg}, \mathrm{Ca}$ ), with a porous structure. Due to the presence of pores with various sizes (usually larger than ions or molecules), zeolites could be used as molecular or ionic filters. The main rock type containing zeolites is zeolitic volcanic tuff.

Clinoptilolite, a member of the heulandite-group of minerals, is abundant in diagenetically altered pyroclastic rocks, particularly in rhyolite-rhyodacite tuffs. It can either form from the alternation of volcanic glass in tuffs or from primary magmatic minerals (Hay, 1981; Hay and Sheppard, 1981, 2001; Esenli and Sirkecioğlu, 2005).

Due to the open tectosilicate-type framework of zeolite minerals, the zeolite bearing rock (i.e. clinoptilolitic volcanic tuff) shows important properties leading to specific possibilities of usage. Applications of zeolitic volcanic tuffs include their usage as cation exchangers in the treatment of municipal and industrial waters (Colella, 1996; Pansini, 1996; Ibrahim and Akashah, 2004), in preparation of lightweight aggregates and cements (Kazantseva et al., 1997; de Gennaro et al., 2004, 2005, 2008), as deodorizers for ammonia-polluted environments (Mumpton, 1996), or as additives to cement (Janotka et al., 2003).

Among other naturally occurring products, clinoptilolite is well suited for all these applications due to its large amount of pore space, high resistance to extreme *Correspondence: H. Bedelean (horea.bedelean@ubbcluj.ro) temperatures, and its chemically neutral structure. The most valuable property of clinoptilolite is its high cation exchange property (CEC).

In Romania, the main zeolitic rocks are represented by volcanic tuffs of Neogene age. The main zeolite present in these rocks is clinoptilolite. The aim of this work is to characterize some Romanian zeolitic volcanic tuffs (Transylvania, Cluj County) and to study their ionic exchange properties with respect to zinc ions. In order to test similar natural materials, our study is concerned with the volcanic tuffs cropping out in the Măcicaş, Apahida and Aluniş areas (Cluj County).

Zinc is a nutritionally essential element, necessary for growth and it has several physiological functions (e.g., protein, DNA, and RNA synthesis). Zinc deficiency results in severe health problems (Roney et al., 2005). On the other hand, excess zinc can be harmful and cause zinc toxicity. Zinc toxicity has been documented in humans as well as in a wide range of large, small, exotic and wild animals (Aizenberg et al., 2006). In case of humans, too much zinc will interfere with the metabolism of other minerals in the body, particularly iron and copper. Symptoms of zinc toxicity (e.g., nausea, gastric distress, anaemia) occur after ingestion of $2 \mathrm{mg}$ of zinc or more (Aizenberg et al., 2006).

Zinc enters the environment in a number of ways. Some is released through natural processes but most comes from human activities. These activities include mining, coal burning, steel production, and the burning of waste. Zinc 
attaches to soil, sediments and dust particles in the air. Its compounds can move into the ground water as well as lakes, streams, and rivers (Roney et al., 2005).

In wastewaters, zinc is mainly found as $\mathrm{Zn}^{2+}$, together with other heavy metal ions such as $\mathrm{Pb}^{2+}, \mathrm{Ni}^{2+}, \mathrm{Co}^{2+}, \mathrm{Cu}^{2+}$, and $\mathrm{Cd}^{2+}$, which all contributes to environmental pollution. These heavy metals are discharged in surface waters or infiltrated in ground waters from various sources including improperly treated industrial wastewaters (e.g., electroplating wastewaters), accidental spills, incomplete collection of used batteries or mining solids, and liquid wastes (Kim et al., 2001; Li and Li, 2001).

Heavy metal ions can be removed from wastewaters using a variety of methods such as precipitation, solvent extraction, vacuum evaporation, membrane technologies, adsorption, and ionic exchange (Ouki and Kavannagh, 1997; Kim et al., 2000; Alvarez-Ayuso et al., 2003; AlvarezAyuso and Garcia-Sanchez, 2003; Chantawong et al., 2003; Erdem et al., 2004).

The behavior of the natural zeolites and clay minerals from different regions of the world have been studied during the ammonium and heavy metal ions removal processes (adsorption and ionic exchange processes). For example, clinoptilolite, which is the most abundant natural zeolite (Italy, Croatia, Turkey, Greece, and Romania) was shown to be an efficiently remover of $\mathrm{NH}_{4}^{+}, \mathrm{Zn}^{2+}, \mathrm{Pb}^{2+}, \mathrm{Ni}^{2+}, \mathrm{Co}^{2+}, \mathrm{Cu}^{2+}, \mathrm{Cr}^{3+}$, $\mathrm{Cd}^{2+}$, and $\mathrm{Mn}^{2+}$ ions from wastewaters (Ouki and Kavannagh, 1997; Langella et al., 2000; Cincotti et al., 2001; Alvarez-Ayuso et al., 2003; Badillo-Almaraz et al., 2003; Panayotova and Velikov, 2003; Erdem et al., 2004; Peric et al., 2004; Top and Ulku, 2004; Bedelean et al., 2006; Stanca et al., 2006; Burcă et al., 2008). Clinoptilolite can also be used as an amendment to sewage sludge or soil in order to stabilize the heavy metal ions and to prevent their entering in the ecosystem by leaching (Zorpas et al., 2000a, 2000b, 2002; Moirou et al., 2001).

Numerous studies on the adsorption properties of clay minerals including bentonite (Ca-, Na- or organic modified bentonite) and kaolin (Kapoor and Viraraghavan, 1998; Dimirkou et al., 2002; Alvarez-Ayuso and Garcia-Sanchez, 2003; Chantawong et al., 2003; Ulusoy et al., 2003; Usman et al., 2004) were carried out.

Adsorption of heavy metals in the mixture solutions by kaolin follows the next sequence: $\mathrm{Cr}>\mathrm{Zn}>\mathrm{Cu} \approx \mathrm{Cd} \approx \mathrm{Ni}>\mathrm{Pb}$ (Chantawong et al., 2003). In the case of $\mathrm{Ca}-$ and $\mathrm{Na}-$ bentonite heavy metals were found to be retained according to the following sequence: $\mathrm{Cr}>\mathrm{Cu}>\mathrm{Ni}>\mathrm{Zn}>\mathrm{Cd}$ (Chantawong et al., 2003). Results for heavy metal ions removal by adsorbents such as modified lignin (Koch and Roundhill, 2001), Typha latifolia plants grown in a mixture of mature sewage sludge compost, commercial compost and perlite (Manios et al., 2003), fish scales (Mustafiz et al., 2002), and fungal biomass (Sag, 2001) were also reported.

\section{MATERIALS AND METHODS}

Natural zeolitized volcanic tuffs were collected from Măcicaş, Aluniş, and Apahida areas (Cluj County, Romania). The pyroclastic rocks belong to the Dej Tuff Complex of Lower Badenian age (Măcicaş and Aluniş Studia UBB, Geologia, 2010, 55 (1), 9 - 15 outcrops) and Upper Badenian Borşa-Apahida tuff Level (Apahida outcrop). The main rock unit is a white to greysh volcanic tuff interlayered with clays, marls, and clayey sandstones (Mârza et al., 1991). The intensive alteration processes (represented mainly by zeolitization, silicifiation, bentonitization, and calcification) affecting these tuffs, led to the formation of economically valuable deposits (e.g., Măcicaş).

\section{Compositional investigations}

Zeolitic tuff samples were investigated by means of optical microscopy, scanning electron microscopy (SEM), X-ray diffraction (XRD), and wet chemical analyses. Bulk homogeneous rock samples were used for the investigations and experiments (zeolite was not separated from the rock mass).

The petrographic observations (identification of the various mineralogical phases, their quantification and the structural description of the material) were made with a Zeiss AxioLab optical microscope on thin sections.

The micromorphological features of zeolite tuffs were examined on silver-coated, fresh surfaces of the selected samples using a JEOL JSM 5510LV scanning electron microscope (SEM). The whole-rock chemistry was determined at ICEI (Physico-Chemical Analyses Centre) Cluj-Napoca using standard analytical methods for silicate materials (wet chemistry).

X-ray diffraction analyses on random powders were performed using a Siemens Bruker unit with $\mathrm{Cu} \mathrm{K \alpha}$ anticathode. The diffraction patterns were recorded from $10^{\circ}$ to $70^{\circ} 2 \theta$. The analytic conditions are $40 \mathrm{~A}, 40 \mathrm{kV}$, steps of $2^{\circ} 2 \theta$. In order to determine the mineral composition, a semi-quantitative X-ray diffraction method was used.

\section{Experimental ionic exchange process}

$\mathrm{Zn}^{2+}$ removal was tested on three bulk samples of zeolitic volcanic tuffs: Măcicaş (M2), Aluniş (A1), and Apahida (Ap). The samples were subjected to the following treatments: mechanical treatment (Fig. 1a), acidic treatment (Fig. 1b), and alkaline treatment (Fig. 1c). During the mechanical treatment, bulk samples were milled to the desired grain size $(0.2-0.4 \mathrm{~mm})$ and then washed in order to remove fine particles from the grain surface, while throughout the acidic treatment $(\mathrm{HCl} 1 \mathrm{M})$ zeolitic volcanic tuff channels are cleared and pores opened. To bring the zeolitic volcanic tuff in $-\mathrm{Na}$ form, which proved to be more efficient in the ionic exchange process (Iovi et al., 1993; Mondale et al., 1995; Cobzaru et al., 2002; Panayotova and Velikov, 2003), the samples were further subjected subsequently to an alkaline treatment $(\mathrm{NaCl} 1 \mathrm{M}$, $\mathrm{pH}=10$ with $\mathrm{NaOH}$ ).

For the ionic exchange study a model solution containing $\mathrm{Zn}^{2+}$ ions $\left(200 \mathrm{mg} / \mathrm{dm}^{3}\right)$ was prepared from $\mathrm{ZnSO}_{4} \cdot 7 \mathrm{H}_{2} \mathrm{O}$ (p.a. reagent). Experiments were realised at $\mathrm{t}=20^{\circ} \mathrm{C}$ without $\mathrm{pH}$ adjustment. Determination of zinc ions in solution was realised using a Jenway 3330 spectrophotometer $(\lambda=420 \mathrm{~nm})$.

The ionic exchange process was first performed in a batch reactor with immobile solid and liquid phases, using $10 \mathrm{~g}$ of the $0.2-0.4 \mathrm{~mm}$ grain size zeolitic tuff and $100 \mathrm{ml}$ zinc ions solution (zeolite : solution $=1: 10$ ). Solution samples were collected every 24 hour for $\mathrm{Zn}^{2+}$ concentration measurement, until equilibrium was reached. 


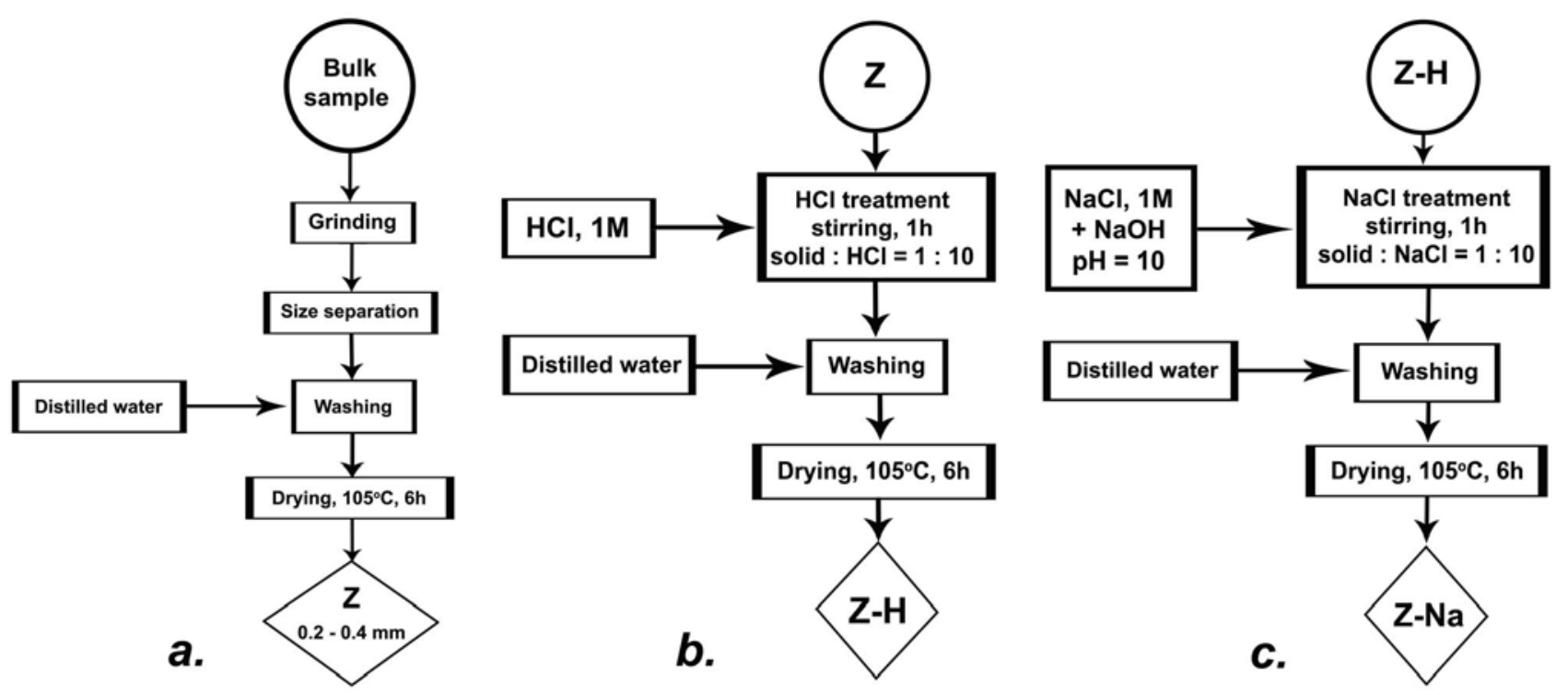

Fig. 1. Zeolitic volcanic tuff treatment methodology: a) mechanical treatment; b) acidic treatment; c) alkaline treatment.

The ionic exchange process was also performed using a fixed bed column $\left(\mathrm{d}_{\mathrm{i}}=15 \mathrm{~mm}\right)$ containing $5 \mathrm{~g}$ of the 0.2 $0.4 \mathrm{~mm}$ grain size zeolitic tuff (the range of the grain size was chosen after prior experiments in order to minimize internal diffusion limitations and to avoid pressure drops in the column bed) with a flow rate of $0.055 \mathrm{ml} / \mathrm{s}$. The flow rate was chosen in order to minimize external diffusion limitations. Every $100 \mathrm{~cm}^{3}$ (ca. 30 minutes) of the effluent $\mathrm{Zn}^{2+}$ solution was collected at the outflow of the column until zeolitic tuff was exhausted, in order to determine the exact concentration of zinc ions and its evolution during the ionic exchange process.

The ionic exchange process takes place according to the following equation:

$$
2 \mathrm{Z}-\mathrm{Na}+\mathrm{Zn}^{2+}=\mathrm{Z}_{2}-\mathrm{Zn}+2 \mathrm{Na}^{+}
$$

Cation exchange capacities (CEC), Q in $\mathrm{mg} \mathrm{Zn}^{2+} / \mathrm{g}$ zeolitic volcanic tuff, and removal efficiencies, E (\%) were calculated using equations (1) and (2) in order to establish the efficiency of the zeolitic volcanic tuff samples during the zinc ion removal process (the calculated values of CEC and removal efficiencies should be regarded according to the precision of the determination methods we used). For the experiments done in a fixed bed column, the breakthrough curves were plotted and the exhaustion point CECs were calculated. In this study, we will refer to the CEC as "practical capacity" or "operating capacity" obtained under the chosen working conditions (Inglezakis, 2005; Fanfan et al., 2006).

$$
Q=\frac{C_{i}-C_{t}}{m} \cdot \frac{V}{1000}
$$

where,

$\mathrm{Q}=$ cation exchange capacity, in $\mathrm{mg} / \mathrm{g}$

$\mathrm{C}_{\mathrm{i}}=$ initial zinc concentration in solution, in $\mathrm{mg} / \mathrm{dm}^{3}$

$\mathrm{C}_{\mathrm{t}}=$ zinc concentration in solution at time $\mathrm{t}$, in $\mathrm{mg} / \mathrm{dm}^{3}$

$\mathrm{V}=100 \mathrm{~cm}^{3}$

$\mathrm{m}=$ zeolite quantity, in $\mathrm{g}$.

$$
E=\frac{C_{i}-C_{t}}{C_{i}} \cdot 100
$$

where,

$\mathrm{E}=$ removal efficiency, in \%

$\mathrm{C}_{\mathrm{i}}=$ initial zinc concentration in solution, in $\mathrm{mg} / \mathrm{dm}^{3}$

$\mathrm{C}_{\mathrm{t}}=$ zinc concentration in solution at time $\mathrm{t}$, in $\mathrm{mg} / \mathrm{dm}^{3}$.

\section{RESULTS AND DISCUSSIONS}

\section{Petrographic results}

According to the amounts of glass, crystals and lithic fragments, the volcanic tuffs from the study area can be mainly classified as vitric and vitric-crystal types.

The volcanic glass represents the main component of the tuffs $(70-80 \%)$, the former glass shards being pseudomorphically replaced by zeolites (clinoptilolite). The overall mineralogical composition is used for defining the tuff's petrographical types. All studied samples consist of dacitic and rhyodacitic tuffs. The primary magmatic minerals are K-feldspars, plagioclases, quartz, biotite, and amphiboles. Small clasts of quartzite and schists from the basement are dominant among the lithic fragments.

In this region, significant amounts of volcanic glass in the pyroclastic sequence have been replaced by zeolites (between 50-80\%). The main zeolite species identified in the volcanic tuffs from Cluj County are clinoptilolite with lesser amounts of phillipsite and mordenite.

The tuffs, from all three occurrences, contain abundant tabular clioptilolite crystals that formed by the replacement of the vitric fragments. Opal-CT lepispheres (Fig. 2a) commonly coexist with clinoptilolite in the Apahida samples. The clinoptilolite crystals occur as euhedral tabular crystals, averaging about 4-10 $\mu \mathrm{m}$, sometimes reaching $30-40 \mu \mathrm{m}$ in size (Figs. 2a, b). The process of zeolitization, of a sin- and diagenetic nature (halmyrolysis), took place in a marine, alkaline environment at a pH between 9.5-9.8 and it was a one-way process: primary material (glass, crystals) $\rightarrow$ zeolites (Bedelean and Stoici, 1984).

From XRD patterns obtained on whole rock samples, only one zeolite species, i.e. clinoptilolite (heulandite group minerals) occurs in all the three studied occurrences (Măcicaş, Aluniş, and Apahida). The semi-quantitative estimation of the XRD patterns indicates that zeolites 
represent between $60 \%$ and $70 \%$ of the crystallized fractions of Aluniş and Măcicaş tuffs and only $40-50 \%$ in Apahida tuff.

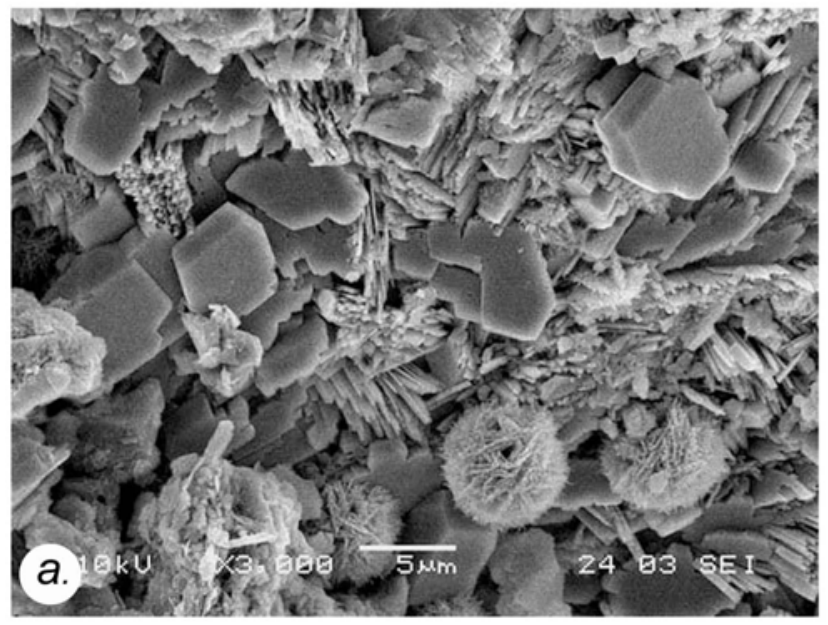

According to the microscopic observations, the other minerals identified are quartz, feldspar, and probably clay minerals (Fig. 3).

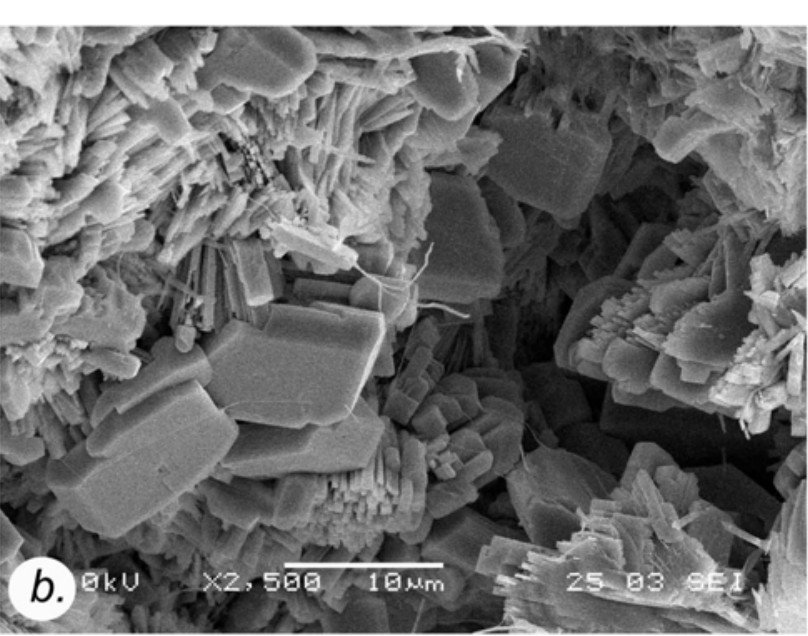

Fig. 2. SEM images of glass shards. a) Clinoptilolite crystals with opal-CT spheres (Apahida); b) SEM images of glass shards. Clinoptilolite crystals (Aluniş).

By taking into account the complex processes that pyroclastic rocks undergo during sedimentation and diagenesis (zeolitization), one has to keep in mind that the chemistry of tuffs does not fully reflect the petrochemical features of the original magma, as it is the case with regular magmatic rocks.

Whole-rock analyses were made on tuffs from Măcicaş, Aluniş, and Apahida. The sampled tuffs from the studied area show a remarkable homogeneity in their mineralogical and chemical composition.

The variation in $\mathrm{SiO}_{2}$ content among the analyzed samples is small. In general, the tuffs are low in $\mathrm{Na}$ and $\mathrm{K}$, but higher in Ca (Table 1). The high amount of secondary and hydrated material (zeolite or smectitic clay minerals) is indicated by the high values of L.O.I. (up to 14\%). No systematic or significant chemical variation within the tuff units, either vertically or laterally, was identified during this study.

Table 1. Chemical composition of the zeolitic tuff samples.

\begin{tabular}{lccccccccc}
\hline Occurrence & \multicolumn{7}{c}{ Oxides wt. \% } \\
\hline & $\mathbf{S i O}_{2}$ & $\mathbf{T i O}_{2}$ & $\mathbf{A l}_{2} \mathbf{O}_{\mathbf{3}}$ & $\mathbf{F e}_{2} \mathbf{O}_{3}$ & $\mathbf{C a O}$ & $\mathbf{M g O}$ & $\mathbf{N a}_{2} \mathbf{O}$ & $\mathbf{K}_{\mathbf{2}} \mathbf{O}$ & L.O.I. \\
\hline Măcicaș & 63.98 & 0.35 & 14.53 & 1.71 & 5.46 & 0.23 & 1.00 & 0.88 & 11.86 \\
Apahida & 65.08 & 0.46 & 13.28 & 2.40 & 3.53 & 1.40 & 2.05 & 1.85 & 9.82 \\
Aluniș & 62.06 & 0.34 & 14.07 & 1.61 & 5.72 & 0.96 & 0.35 & 0.86 & 14.23 \\
\hline
\end{tabular}

\section{Ionic exchange results}

Variation in the zinc ions concentration in time for M2-Na, A1-Na, and Ap-Na samples in batch conditions (zeolitic volcanic tuff and zinc solution as immobile phases) are presented in Fig. 4a. For all three samples, the $\mathrm{Zn}^{2+}$ ions concentration shows similar decrease with the reaction time. The $\mathrm{Zn}^{2+}$ ions concentration drops from the initial $200 \mathrm{mg} / \mathrm{dm}^{3}$ to about $90 \mathrm{mg} / \mathrm{dm}^{3}$ during the first 24 hours for the Ap sample and to about 42 and $58 \mathrm{mg} / \mathrm{dm}^{3}$ for A1 and M2, respectively. The ionic exchange efficiency reached values around $80 \%$ (Fig. $4 \mathrm{~b}$ ) in case of A1 sample. The equilibrium was reached after about 48 hours for all samples. The maximum quantities of $\mathrm{Zn}^{2+}$ exchanged on mass unit $(\mathrm{g})$ of zeolitic tuff sample are $1.44,1.55$, and $1.05 \mathrm{mg} \mathrm{Zn}^{2+}$ zeolitic tuff for M2, A1, and Ap samples, respectively.

The decrease of the $\mathrm{Zn}$ concentration in the water proves that the ionic exchange reaction took place. Therefore, the Studia UBB, Geologia, 2010, 55 (1), 9 - 15 zeolitic tuffs under study are considered to be active in the ionic exchange process. Among the considered samples, The A1 zeolitic tuff sample proved to be most efficient in the ionic exchange process in batch conditions. Since there is no significant difference in clinoptilolite content of the samples, the difference observed might be due to the porous structure of the bulk samples.

In the fixed bed colums experiments, we used $\mathrm{Zn}^{2+}$ concentrations determined at the outflow of the column, to plot the breakthrough curves for M2 and A1 zeolitic samples (Fig. 5). By detail inspection of these curves some differences were identified. The slope of the breakthrough curve increases for the A1 sample, implying higher accessibility of the internal surface for this sample and therefore minimal internal diffusion limitations. Consequently, the exhaustion of this zeolitic sample will take place more rapidly, exhaustion taking place at about 180 minutes, in comparison with 210 minutes for M2 sample. 

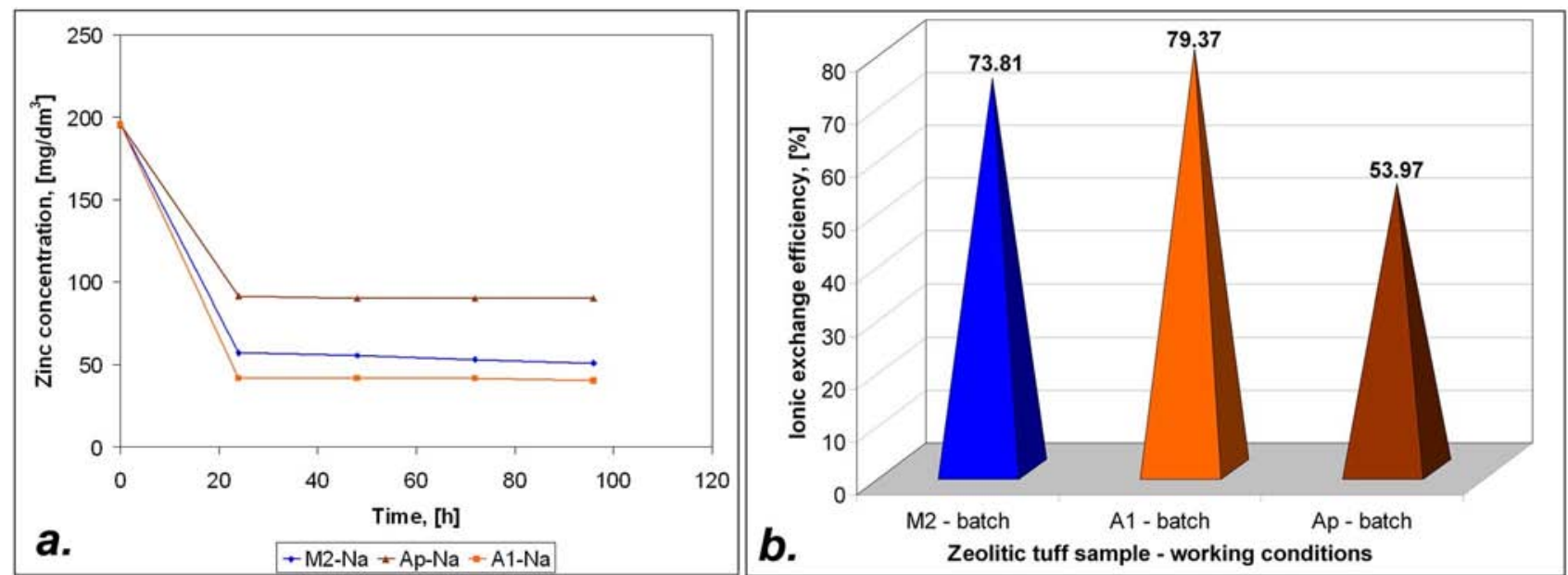

Fig. 4. a) Evolution of $\mathrm{Zn}^{2+}$ concentrations versus time during the adsorption experiment in batch conditions (immobile phases) for the Măcicaş, Apahida and Aluniş samples in-Na form; b) Maximum ionic exchange efficiency for M2, A1 and Ap samples in-Na form for zinc ions removal in batch conditions (immobile phases).

The results of the experiments done in the fixed bed column confirm the results obtained in static regime. The data show that the A1 sample is more accessible for zinc ion exchange. After 30 minutes, zinc concentration drops to $59 \mathrm{mg} / \mathrm{dm}^{3}$ when compared to the initial $200 \mathrm{mg} / \mathrm{dm}^{3}$. In comparison, the M2 sample's (same time interval and initial concentration) concentration drops to $125.78 \mathrm{mg} / \mathrm{dm}^{3}$. Accordingly, at the end of the experiment (i.e., the exhaustion of the zeolitic sample), the exchanged zinc quantity will be higher for the A1 sample (5 mg $\mathrm{Zn}^{2+} / \mathrm{g}$; Fig. 6), compared with $4.66 \mathrm{mg}$ $\mathrm{Zn}^{2+} / \mathrm{g}$ for $\mathrm{M} 2$ sample. As a consequence of the higher removal rate on the A1 zeolitic sample, the exhaustion will take place more rapidly, therefore, will require regeneration more often.

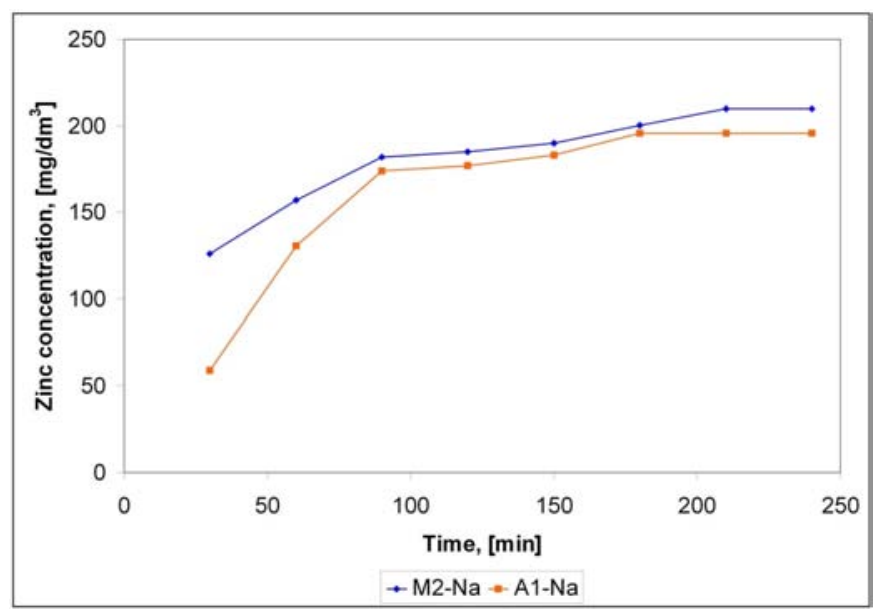

Fig. 5. Evolution of $\mathrm{Zn}^{2+}$ concentrations (breakthrough curves) during the ionic exchange experiment in fixed bed column experiments for the M2-Na and A1-Na samples.

The results obtained for the three samples considered in both batch and fixed bed conditions are summarised in Fig. 7 by means of the maximum values (equilibrium and exhaustion point) for the cation exchange capacity (exchanged $\mathrm{Zn}^{2+}$ quantities/g zeolitic tuff). For all samples these values are higher in fixed bed conditions, which are more appropriate for an industrial application.

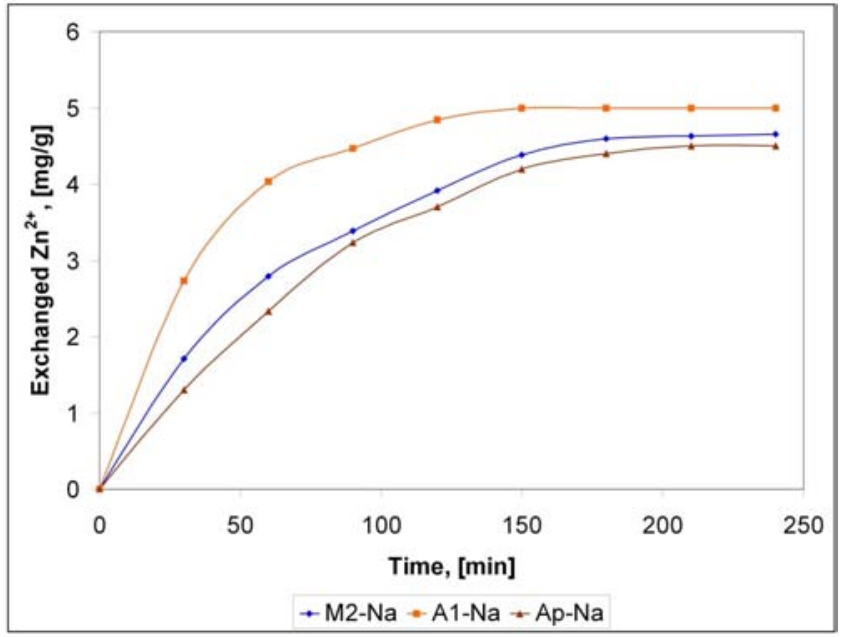

Fig. 6. Evolution of the exchanged $\mathrm{Zn}^{2+}$ quantities (CEC) on the zeolitic tuff samples during the ionic exchange experiment in fixed bed column experiments.

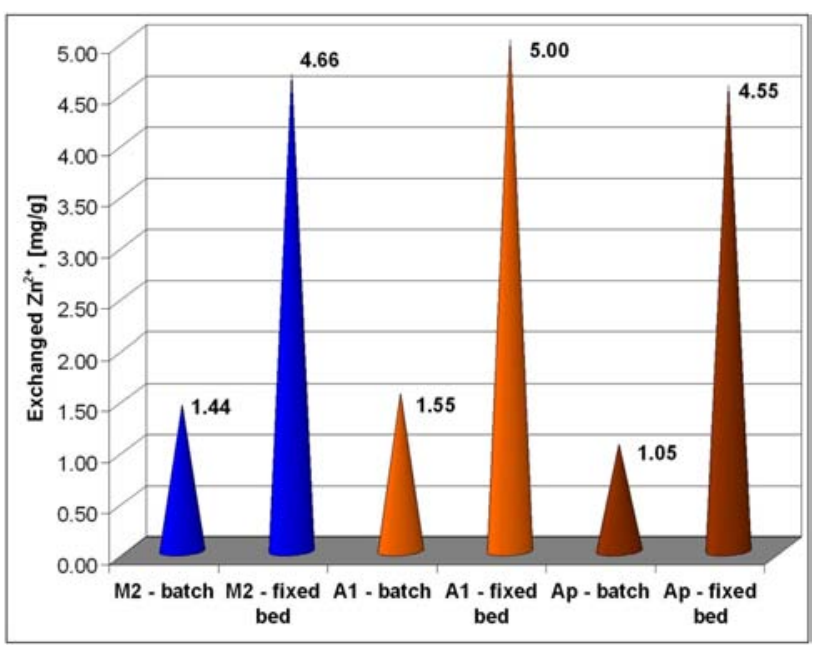

Fig. 7. Exchanged $\mathrm{Zn}^{2+}$ quantities (CEC) on the three samples considered in batch conditions (equilibrium) and fixed bed column experiments (exhaustion point).

Therefore, in order to choose the most appropriate zeolitic sample to be used at industrial level it would be important to take into account several factors such as: 
breakthrough point, cation exchange capacity at exhaustion point, timescale, and the regeneration frequencies.

Further studies will focus on establishing the appropriate conditions for the zeolitc tuff samples regeneration: regeneration reagents, flow rate, duration, and number of regeneration cycles on which a specific sample can be subjected.

\section{CONCLUSIONS}

The results obtained for the three zeolitic tuff samples, in both batch and fixed bed conditions, are presented by means of CEC (exchanged $\mathrm{Zn}^{2+}$ quantities/g zeolitic tuff), and removal efficiency (for batch conditions).

The ionic exchange reaction occured for all samples, therefore, the zeolitic tuffs under study were shown to be active in the ionic exchange process. For both batch and fixed bed conditions, the ionic exchange efficiency (with respect to cation exchange capacity reached at the equilibrium and breakthrough point, respectively) increases in the following order: Ap $<\mathrm{M} 2<\mathrm{A} 1$. In fixed bed column experiments, the CEC values are much higher, proving the additional capacity of the zeolitic volcanic tuff to retain metal ions from solution (wastewaters).

Due to the higher zeolite content, the Dej tuff (Lower Badenian age) is more efficient in removal of zinc ions from solution, than the tuff belonging to the Borşa-Apahida Level (Upper Badenian age).

Among the studied samples, the Aluniş tuff proved to be more efficient in the ionic exchange process, in both batch and fixed bed conditions, due to the slightly higher content of zeolite and higher porosity. The latter allows a better diffusion of the $\mathrm{Zn}^{2+}$ ions from the solution and a higher retention of $\mathrm{Zn}^{2+}$.

Our study shows that zeolitic volcanic tuffs from Cluj County (Romania) can be successfully used to remove zinc ions from solution and wastewaters.

Acknowledgements. This study has received financial support from the Romanian Ministry of Education (CNCSIS) project 1754.

\section{R E F E R E N C E S}

Aizenberg, I., Miara, L. \& Ulman, O. 2006, Heavy metal toxicity in psittacine birds. Israel Journal of Veterinary Medicine, 61 (1): 28-29.

Alvarez-Ayuso, E., Garcia-Sanchez, A. \& Querol, X. 2003, Purification of metal electroplating waste waters using zeolite. Water Research, 37 (20): 4855-4862.

Alvarez-Ayuso, E., Garcia-Sanchez, A. 2003, Removal of heavy metals from waste waters by natural and $\mathrm{Na}-$ exchanged bentonites. Clay and Clay Minerals, 51 (5): 475-480.

Badillo-Almaraz, V., Trocellier, P. \& Davila-Rangel, I. 2003, Adsorption of aqueous $\mathrm{Zn}$ (II) species on synthetic zeolites. Nuclear Instruments and Methods in Physics Research, B210: 424-428.

Bedelean, H., Stanca, M., Măicăneanu A. \& Burcă, S. 2006, Zeolitic volcanic tuffs from Măcicaş (Cluj County), natural raw materials used for $\mathrm{NH}_{4}^{+}$removal from wastewaters. Studia Universitatis Babeş-Bolyai, Geologia, 51: 43-49.
Bedelean, I., Stoici, S. 1984, Zeoliți. Ed. Tehnică, Bucureşti, $227 \mathrm{p}$.

Burcă, S., Vermeşan, G., Bulea, C., Stanca, M., Măicăneanu, A. \& Bedelean, H. 2008, Removal of iron and ions zinc from electroplating wastewaters by ionic exchange. Journal of Environmental Protection and Ecology, 94 (4): 868-882.

Chantawong, V., Harvey, N.W. \& Bashkin, V.N. 2003, Comparison of heavy metal adsorptions by Thai kaolin and ballclay. Water, Air and Soil Pollution, 148: 111-125.

Cincotti, A., Lai, N., Orru, R. \& Cao, G. 2001, Sardinian natural clinoptilolite for heavy metals and ammonium removal: experimental and modelling. Chemical Engineering Journal, 84 (3): 275-282.

Cobzaru, C., Oprea, S., Hulea, T., Hulea, V. \& Dumitriu, E. 2002, Aplicații ale zeoliților naturali în eliminarea metalelor din apele uzate şi catalizarea unor reacţii chimice organice. Revista de Chimie, 53 (10): 674-677.

Colella, C. 1996, Ion exchange equilibria in zeolite minerals. Mineralium Deposita, 31 (6): 554-562.

de Gennaro, R., Cappelletti, P., Cerri, G., de Gennaro, M., Dondi, M. \& Langella, A. 2004, Zeolitic tuffs as raw materials for lightweight aggregates. Applied Clay Science, 25 (1-2): 71-81.

de Gennaro, R., Cappelletti, P., Cerri, G., de Gennaro, M., Dondi, M. \& Langella, A. 2005, Neapolitan Yellow Tuff as raw material for lightweight aggregates in lightweight structural concrete production. Applied Clay Science, 28 (1-4): 309-319.

de Gennaro, R., Langella, A., D'Amore, M., Dondi, M., Colella, A., Cappelletti, P. \& de Gennaro, M. 2008, Use of zeolite-rich rocks and waster materials for the production of structural lightweight concretes. Applied Clay Science, 41 (1-2): 61-72.

Dimirkou, A., Ioannou, A., Papadopoulus, P. \& Paschalidou, C. 2002, Zinc sorption by kaolinite: influence of $\mathrm{pH}$, electrolyte, and initial $\mathrm{Zn}$ concentrations with simultaneous release of $\mathrm{Mg}, \mathrm{Ca}, \mathrm{Mn}$, and $\mathrm{Cu}$ ions. Communications in Soil and Science and Plant Analysis, 33: 2917-2934.

Erdem, E., Karapinar, N. \& Donat, R. 2004, The removal of heavy metal cations by natural zeolites. Journal of Colloidal and Interface Science, 280 (2): 309-314.

Esenli, F., Sirkecioğlu, A., 2005, The relationship between zeolite (heulandite-clinoptilolite) content and the ammonium-exchange capacity of pyroclastic rocks in Gördes, Turkey. Clay Minerals, 40 (4): 557-564.

Fanfan, P.N., Mabon, N., Thonart, P., Lognay, G., Copin, A. \& Barthelemy, J.-P. 2006, Investigations on cationic exchange capacity and unused bed zone according to operational conditions in a fixed bed reactor for water lead removal by a natural zeolite. BASE, 10: 93-99.

Hay, R.L. 1981, Geology of zeolites in sedimentary rocks. In Mineralogy and geology of natural zeolites (Mumpton, F.A., Ed.), Mineralogical Society of America, Washington D.C., p. 53-64.

Hay, R.L., Sheppard A.R. 1981, Zeolites in open hydrologic systems. In Mineralogy and geology of natural zeolites (Mumpton, F.A., Ed.), Mineralogical Society of America, Washington D.C., p. 93-102.

Hay, R.L., Sheppard, A.R. 2001, Occurrence of zeolites in sedimentary rocks: an overview. In Reviews in Mineralogy and Geochemistry, Natural zeolites, 
occurrence, properties, applications (Bish, D.L., Ming, D.W., Eds.), 45: 217-234.

Ibrahim, K.M., Akashah, T. 2004, Lead removal from wastewater using faujasite tuff. Environmental Geology, 46 (6-7): 865-870.

Inglezakis, V.J. 2005, The concept of "capacity" in zeolite ion-exchange systems. Journal of Colloid Interface Science, 281 (1): 68-79.

Iovi, A., Burtică, G. \& Pode, R. 1993, Studies concerning the natural native zeolites, Chemical Bulletin Technical University, 38 (52): 29-37.

Janotka, I., Krajči, L. \& Dzivák, M. 2003, Properties and utilization of zeolite-blended Portland cements. Clays and Clay Minerals, 51 (6): 616-624.

Kapoor, A., Viraraghavan, T. 1998, Use of immobilized bentonite in removal of heavy metals from wastewater. Journal of Environmental Engineering, 124 (10): 10201024.

Kazantseva, L.K., Belitsky, I.A. \& Fursenko, B.A. 1997, Zeolite-containing rocks as raw material for sibeerfoam production. In Natural zeolites - Sofia '95 (Kirov, G., Filizova, L. \& Petrov, O., Eds.), Pensoft Publishers, p. 33-42, Sofia, Bulgaria.

Kim, J.S., Park, J.C. \& Yi, J. 2000, Zinc ion removal from aqueous solutions using modified silica impregnated with 2-ethylhexyl 2-ethylhexyl phosphoric acid. Separation Science and Technology, 35: 1901-1916.

Kim, S.-O., Moon, S.-H. \& Kim, K.-W. 2001, Removal of heavy metals from soil using enhanced electrokinetic soil processing. Water, Air and Soil Pollution, 125: 259-272.

Koch, H.F., Roundhill, D.M. 2001, Removal of mercury (II) nitrate and other heavy metal ions from aqueous solution by a thiomethylated lignin material. Separation Science and Technology, 36 (1), 137-143.

Langella, A., Pansini, M., Cappelletti, P., de Gennaro, B., de Gennaro, M. \& Colella, C. $2000, \mathrm{NH}_{4}^{+}, \mathrm{Cu}^{2+}, \mathrm{Zn}^{2+}, \mathrm{Cd}^{2+}$ and $\mathrm{Pb}^{2+}$ exchange for $\mathrm{Na}^{+}$in a sedimentary clinoptilolite, North Sardinia, Italy. Microporous and Mesoporous Materials, 37 (3): 337-343.

Li, L.Y., Li, F. 2001, Heavy metal sorption and hydraulic conductivity studies using three types of bentonite admixes. Journal of Environmental Engineering, 127 (5): 420-429.

Manios, T., Stentiford, E.I. \& Millner, P. 2003, Removal of heavy metals from a metaliferous water solution by Typha latifolia plants and sewage sludge compost. Chemosphere, 53 (5): 487-494.

Mârza, I., Codoreanu, F., Hosu, A., Plăceanu, M.L., Marian, D., Pop, R. \& Tămaş, D., 1991, Caractérisation pétrographique synthétique des tufs volcaniques de la région Dej-Cluj-Napoca et signification volcanologique. In The Volcanic Tuffs from the Transylvanian Basin, Romania (Mârza, I., Ed.), p. 171-181, Cluj.

Moirou, A., Xenidis, A. \& Paspaliaris, I. 2001, Stabilization $\mathrm{Pb}, \mathrm{Zn}$, and $\mathrm{Cd}$-contaminated soil by means of natural zeolite. Soil and Sediment Contamination, 10: 251-267.

Mondale, K.D., Carland, R.M. \& Aplan, F.F. 1995, The comparative ion exchange capacities of natural sedimentary and synthetic zeolites. Minerals Engineering, 8 (4-5): 535-548.

Mumpton, F.A. 1996, The natural zeolite story. In Proceedings of the $3^{\text {rd }}$ National Congress - AIMAT, omaggio scientifico a Riccardo Sersale (Colella, C., Ed.), De Frede, p. 31-64, Napoli, Italy.

Mustafiz, S., Basu, A., Islam, M.R., Dewaidar, A. \& Chaalal, O. 2002, A novel method for heavy metal removal. Energy Sources, 24 (11): 1043-1051.

Ouki, S.K., Kavannagh, M. 1997, Performance of natural zeolites for the treatment of mixed metal-contaminated effluents. Waste Management and Research, 15: 383-394.

Panayotova, M., Velikov, B. 2003, Influence of zeolite transformation in a homoionic form on the removal of some heavy metal ions from wastewater. Journal of Environmental Science and Health, A38 (3): 545-554.

Pansini, M., 1996, Natural zeolites as cation exchangers for environmental protection. Mineralium Deposita, 31 (6): 563-575.

Perić, J., Trgo, M. \& Vukojević Medvidović, N. 2004, Removal of zinc, copper and lead by natural zeolite - a comparison of adsorption isotherms. Water Research, 38 (7): 1893-1899.

Roney, N., Smith, C.V., Williams, M., Osier, M. \& Paikoff, S.J. 2005, Toxicological profile for zinc. U.S. Department of Health and Human Services, Public Health Service, Agency for Toxic Substances and Disease Registry.

Sag, Y. 2001, Bioadsorption of heavy metals by fungal biomass and modelling of fungal biosorption: A review. Separation and Purification Technique, 30 (1): 1-48.

Stanca, M., Măicăneanu, A., Burcă, S. \& Bedelean, H. 2006, Removal of some heavy metal ions from wastewaters using natural zeolites. A comparative study. Studia Universitatis Babeş-Bolyai, Chemia, LI (2): 187-196.

Top, A., Ulku, S. 2004, Silver, zinc, and copper exchange in a Na-clinoptilolite and resulting effect on antibacterial activity. Applied Clay Science, 27 (1-2): 13-19.

Ulusoy, U., Simsek, S. \& Ceyhan, O. 2003, Investigations for modification of polyacrylamide-bentonite by phytic acid and its usability in $\mathrm{Fe}^{3+}, \mathrm{Zn}^{2+}$, and $\mathrm{UO}_{2}{ }^{2+}$ adsorption. Adsoprtion, 9 (2): 165-175.

Usman, A.R.A., Kuzyakov, Y. \& Stahr, K. 2004, Effect of clay minerals on extractability of heavy metals and sewage sludge mineralization in soil. Chemistry and Ecology, 20 (2): 123-135.

Zorpas, A.A., Constantinides, T., Vlyssides, A.G., Haralambous, I. \& Loizidou, M. 2000a, Heavy metal uptake by zeolite and metals partitioning in sewage sludge compost. Bioresource Technology, 72: 113-119.

Zorpas, A.A., Kapetanios, E., Zorpas, G.A., Karlis, P., Vlyssides, A.G., Haralambous, I. \& Loizidou, M. 2000b, Compost produced from organic fraction of municipal solid waste, primary stabilized sewage sludge and natural zeolite. Journal of Hazardous Materials, 77 (1-3): 149-159.

Zorpas, A.A., Vassilis, I., Loizidou, M. \& Grigoropoulou, H. 2002, Particle size effects on uptake of heavy metals from sewage sludge compost using natural zeolite clinoptilolite. Journal of Colloid and Interface Science, 250 (1): 1-4. 